\title{
On Not Revisiting Official Discount Rates: Institutional Inertia and the Social Cost of Carbon
}

\section{Citation}

Cass R. Sunstein, On Not Revisiting Official Discount Rates: Institutional Inertia and the Social Cost of Carbon (Olin Center Faculty Discussion Papers 774, 2014).

\section{Published Version}

http://www.law.harvard.edu/programs/olin_center/papers/774_Sunstein.php

\section{Permanent link}

http://nrs.harvard.edu/urn-3:HUL.InstRepos:12921749

\section{Terms of Use}

This article was downloaded from Harvard University's DASH repository, and is made available under the terms and conditions applicable to Open Access Policy Articles, as set forth at http:// nrs.harvard.edu/urn-3:HUL.InstRepos:dash.current.terms-of-use\#OAP

\section{Share Your Story}

The Harvard community has made this article openly available.

Please share how this access benefits you. Submit a story.

Accessibility 


\section{HARVARD}

JOHN M. OLIN CENTER FOR LAW, ECONOMICS, AND BUSINESS

ON NOT REVISITING OFFICIAL DISCOUNT RATES:

INSTITUTIONAL INERTIA AND THE SOCIAL COST OF CARBON

Cass R. Sunstein

Published in American Economic Review: Papers \& Proceedings (2014)

Discussion Paper No. 774

$06 / 2014$

Harvard Law School

Cambridge, MA 02138

This paper can be downloaded without charge from:

The Harvard John M. Olin Discussion Paper Series: http://www.law.harvard.edu/programs/olin_center/

The Social Science Research Network Electronic Paper Collection: $\underline{\text { http://ssrn.com }}$ 
Very preliminary draft-in-progress $10 / 21$

All rights reserved

Forthcoming, American Economic Review: Papers and Proceedings (2014)

\title{
On Not Revisiting Official Discount Rates: Institutional Inertia and the Social Cost of Carbon
}

\author{
Cass R. Sunstein*
}

\begin{abstract}
Within the federal government, official decisions are a product of both substantive judgments and institutional constraints. With respect to discounting, current practice is governed by OMB Circular A-4 and the 2010 and 2013 technical support documents of the Interagency Working Group on the Social Cost of Carbon. Reconsideration of existing judgments must be subjected to a demanding and time-consuming process of internal review (and potentially to external review as well). Institutional constraints, including the need to obtain consensus, can impose obstacles to efforts to rethink existing practices, especially in an area like discounting, which is at once technical and highly controversial.
\end{abstract}

Within the executive branch, important decisions result from both substantive judgments and institutional constraints. The constraints take the form of three sets of costs: decision costs, opportunity costs, and political costs. In exploring the workings of government, economists and economically-oriented law professors have placed far too much emphasis on the role of interest groups and far too little emphasis on a far larger set of institutional constraints, of which interestgroup activity is at most one part. Because of those constraints, it can be costly and difficult to change existing policies, especially because such changes typically require a consensus among diverse people, who may have strong views and who have many demands on their time. For public officials, a degree of institutional inertia is often a product of a considered analysis of the full set of costs and benefits.

With respect to discount rates in the domain of regulation, the central governing document is OMB Circular A-4, issued in 2003 (OMB 2003). Circular A-4 was produced by officials within the executive branch, coming from diverse parts of the federal government; both political appointees and career officials played a role. The Council of Economic Advisers and the Office of Information and Regulatory Affairs (OIRA) were particularly important. An initial version was presented to the public for comments and also subject to peer review. OMB Circular A-4 calls for discount rates of 7 percent ("whenever the main effect of a regulation is to displace

* Robert Walmsley University Professor, Harvard University. The author is grateful to Eric Posner for valuable comments on an earlier draft. 
or alter the use of capital in the private sector") and 3 percent ("when regulation primarily and directly affects private consumption (e.g., through higher consumer prices for goods and services)")(OMB 2003). Emphasizing both ethical considerations and the role of uncertainty with respect to interest rates over time (Weitzman 1998), Circular A-A also allows "a further sensitivity analysis using a lower but positive discount rate" when a rule "will have important intergenerational benefits or costs" (OMB 2003).

With respect to climate change in particular, the relevant guidance, coming in the form of a Technical Support Document, was issued by an Interagency Working Group on Social Cost of Carbon in 2010 (Interagency Working Group 2010; Greenstone, Kopits, and Wolverton 2011). The IWG, which I helped to convene, included representatives of the Council of Economic Advisers, the Council on Environmental Quality, the Department of Agriculture, the Department of Commerce, the Department of Energy, the Department of Transportation, the Environmental Protection Agency, the National Economic Council, the Office of Energy and Climate Change, the Office of Management and Budget, the Office of Science and Technology Policy, and the Department of the Treasury.

The TSD offers a detailed discussion of discount rates and climate change. Noting the well-known differences between prescriptive and descriptive approaches, it relies "primarily on the descriptive approach to inform the choice of discount rate. With recognition of its limitations, we find this approach to be the most defensible and transparent given its consistency with the standard contemporary theoretical foundations of benefit-cost analysis and with the approach required by OMB's existing guidance" (Interagency Working Group 2010, 19). At the same time, the TSD states that "the interagency group has been keenly aware of the deeply normative dimensions of both the debate over discounting in the intergenerational context and the consequences of selecting one discount rate over another" (19).

The TSD opts for three discount rates, designed to span a plausible range of certainty-equivalent rates: $2.5,3$, and 5 percent. The TSD explains that 3 percent corresponds to the after-tax riskless interest rate and that 5 percent reflects "the possibility that climate damages are positively correlated with market returns" and "may be justified by the high interest rates that many consumers use to smooth consumption across periods"(23). The low value of 2.5 percent is used to reflect the uncertainty of interest rates over time (Newell and Pizer 2003), and also to acknowledge "ethical objections that have been raised about rates of 3 percent or higher" (Interagency Working Group 2010, 23). The guidance was updated in 2013, maintaining the three discount rates and with changes not relevant here (Interagency Working Group 2013).

With respect to discount rates, both Circular A-4 and the TSD have been subject to significant criticism. William Nordhaus, for example, contends that in Circular A-4, "the OMB discussion is completely confused," because "the difference is 
not the difference between investment and consumption" but instead "the risk premium on leveraged corporate capital"; he adds that "the numbers are generally reasonable ones to apply" (Nordhaus 2013). Many people believe that the TSD relies on unreliable integrated assessment models (Pindyck, 2013), and also makes the wrong choice of discount rate (Ackerman and Stanton, 2012). On one view, the discount rate used to obtain the central value -3 percent - is too high for ethical reasons (id.; see also Stern, 2013).

Let us stipulate that a new interagency process, designed to produce a fresh analysis and set of conclusions with respect to discounting, could lead to genuine improvements. Even if so, it does not follow that the federal agencies should initiate such a process. To decide whether to do so, they would have to consider the costs and benefits of initiating that very process, and under imaginable assumptions, they might conclude that it would not be worthwhile.

The initial question, of course, is whether such a process would lead to significantly improved judgments; if so, it could have large benefits. Suppose that officials (informed by outside commentators, including Nordhaus) conclude that Nordhaus is essentially right - that the current numbers are reasonable even though the analysis is "completely confused." In that event, the argument for a formal process would not be especially strong, simply because current practice is (by hypothesis) working well enough. To be sure, official documents should avoid complete confusion, but if the ultimate conclusions are not producing bad policies, then it might be best to focus on other, more pressing matters.

Suppose, however, that the existing numbers are not so reasonable, or that with respect to climate change in particular, a significant revision might well be in order (Stern, 2013). Public officials might be convinced (perhaps by academic economists) that existing practice is mistaken. If so, the stakes might be high, because the stringency of significant environmental regulations might be a product of those mistakes (cf. Stern, 2013). For example, regulations involving fuel economy mandates for heavy-duty trucks, and energy efficiency requirements for appliances, might turn out to be insufficiently stringent, or unduly stringent, because of an error that a suitable interagency process might correct.

Even if so, public officials will have to consider the costs of initiating such a process. Recall the large number of participants in the Interagency Working Group on Social Cost of Carbon. Those participants included political appointees as well as civil servants. Within the various departments, all of them were answerable to Cabinet heads, and within the White House, all of them were accountable to the heads of the relevant offices. Although the President is ultimately in charge, the White House is itself a "they," not an "it" (Sunstein 2013), and the same point is even more true for the executive branch as a whole. For an issue of this importance and complexity, Cabinet heads and leaders of White House offices are likely to have a degree of personal involvement. Such officials have a wide range of obligations, and differing levels of expertise and commitment, and it is no light thing to ask them to 
spend their time on reassessing a technical document of this kind. The benefits of the reassessment might turn out to justify the costs, but here as elsewhere, the idea of "bandwidth" is exceptionally important (Mullainathan and Shafir 2013).

The problem might be compounded by the difficulty of achieving consensus. Institutional inclinations might produce divergent (and apparently firm) initial judgments. Discussions of discount rates will almost certainly trigger strong reactions from at least some knowledgeable participants, and they might not be in accord, certainly at the inception, and perhaps after extended discussion as well. It would not be terribly surprising to find that the Council of Economic Advisers and the National Economic Council, drawing on standard economic thinking, favor something in the range of a 5 percent rate, while the Environmental Protection Agency and the Council on Environmental Quality, influenced by critiques of that thinking and highly attentive to the interests of future generations (Stern, 2013), favor a lower rate. That discussion must be mediated, and there is no self-evident mediator. If the effort to achieve a consensus breaks down, the default will of course be existing practice, and hence there may be a question whether it makes sense to embark on an interagency process without a degree of confidence, in advance, that it will be feasible to achieve that consensus. To be sure, the difficulty of achieving agreement need not be a decisive objection to efforts to improve a document that is both flawed and damaging; but that difficulty might well produce a degree of internal caution.

There is also a question whether the resulting documents should be subject to peer review, public comment, or both. Circular A-4 was subject to both, apparently on the theory that those outside of government had important information, and the final version of the document would benefit from that information. Officials might also have believed that peer review and public comment would have a legitimating function, reducing the risk of public or congressional disapproval. Neither the 2010 TSD nor the 2013 update was subject to peer review in advance, though an interim version was subject to public comment in 2009. (After both documents were issued, numerous comments were received.)

For any general effort to rethink discount rates for regulatory policy, some people inside and outside of the executive branch would likely argue in favor of both peer review and public comment in advance. When it is working well, both the internal process and public scrutiny can produce an admirable form of "government by discussion" (Sen 2009). At the same time, it is not irrelevant to recall, in this context, Oscar Wilde's admonition that one problem with socialism is that it can "take too many evenings." With respect to discount rates, especially for the longterm future, peer reviewers are likely to differ intensely; public commentators will certainly do so. Those inside government will have to evaluate the underlying disagreements, and even if they are professional economists, they might not be entirely confident about the right answers. 
Nothing said thus far specifies a role for "politics," or for interest groups, within the executive branch. As suggested above, economists and economically oriented law professors often overstate the role of interest groups within that branch of government. (Outside observers might be surprised to learn that such groups played no role at all in the deliberations that led to the social cost of carbon in 2010.) Nonetheless, it is quite possible that any effort to rethink discount rates would require at least a degree of attention from both the White House Office of Legislative Affairs and the White House Office of Communications.

The former office, entrusted with managing relationships with Congress, will be interested in knowing whether the enterprise will create serious difficulty, and at least for some participants, it may not be an irrelevant question whether any such difficulty is worth incurring. Although the social cost of carbon received little congressional attention between 2009 and 2012, there was a flurry of legislative activity and concern in 2013 (in the aftermath of Interagency Working Group, 2013), and the executive branch might not particularly welcome such activity and concern. (It is also true that in spurring congressional activity, interest groups can play a significant role.) The costs of responding to Congress, perhaps through testifying in hearings (one of whose primary purposes may be to embarrass the Administration), are real. While those costs are most unlikely to be determinative of a judgment about whether, when, and exactly how to proceed, they might not be entirely irrelevant to the calculus.

In addition, the Office of Communications must manage relationships with the media. As in the case of the Office of Legislative Affairs, that office is not likely to play a significant role with respect to technical questions. But some officials may not be indifferent to the question whether it is necessary or appropriate to create some kind of public stir, especially on such questions. The "bandwidth" issue might be relevant here as well.

This understanding of the costs of decision within the executive branch raises an obvious question, which is whether existing processes are excessive, insufficient, or optimal. A central goal of such processes is to minimize the sum of error costs and decision costs. More streamlined processes, reducing decision costs, would make it easier to overcome inertia, but they might also increase the likelihood of error (understood in purely technical terms). In principle, it might seem best to reserve the process to genuine specialists and to let them make the appropriate substantive judgments (subject perhaps to peer review and public comment). It must be acknowledged that some people who are involved in the assessment of discount rates, the social cost of carbon, and related topics are informed observers rather than genuine specialists. At the same time, there is a risk that specialists will miss something of importance or relevance, and hence the inclusion of informed observers may help to reduce errors. A particular judgment about the optimal level of "government by discussion," in a system that is abstractly committed to that idea, cannot be defended in the abstract. 
In view of the procedural checks outlined here, public officials must often think some version of the old adage, "if it ain't broke, don't fix it." In view of their particular role, they might sometimes even think, "if it ain't badly broke, don't get anywhere near it." With respect to discount rates and related topics, it is true that the institutional constraints discussed here can lead to a kind of inertia. It is also true that within government, such inertia should often be, and often is, overcome, because the relevant costs, even if real, are far from sufficient to justify maintaining an imperfect or damaging status quo. But within government, inertia can be a product not of a behavioral bias, but of a vivid awareness of the full range of costs and benefits. 


\section{References}

Ackerman, Frank and Elizabeth A. Stanton. 2012. "Climate Risks and Carbon Prices: Revising the Social Cost of Carbon." Economics: The Open-Access, OpenAssessment E-Journal 6(2012-10): 1-25. http://dx.doi.org/10.5018/ economicsejournal.ja.2012-10.

Greenstone, Michael, Elizabeth Kopits, and Ann Wolverton. 2011. "Estimating the Social Cost of Carbon for Use in U.S. Federal Rulemakings: A Summary and Interpretation." NBER Working Paper No. 16913. http://www.nber.org/papers/ w16913.

Interagency Working Group on Social Cost of Carbon, United States Government. 2010. "Technical Support Document: the Social Cost of Carbon for Regulatory Impact Analysis Under Executive Order 12866." http://www.epa.gov/otaq/climate/regulations/scc-tsd.pdf.

Interagency Working Group on Social Cost of Carbon, United States Government. 2013. "Technical Support Document: -Technical Update of the Social Cost of Carbon for Regulatory Impact Analysis - Under Executive Order 12866." http://www.whitehouse.gov/sites/default/files/omb/inforeg/social_cost_of_carbo n_for_ria_2013_update.pdf.

Mullainathan, Sendhil and Eldar Shafir. 2013. Scarcity: Why Having Too Little Means So Much. New York: Times Books.

Newell, Richard G., and William A. Pizer. 2003. "Discounting the Distant Future: How Much Do Uncertain Rates Increase Valuations?" Journal of Environmental Economics and Management 46 (1): 52-71.

Nordhaus, William. 2013. The Climate Casino: Risk, Uncertainty, and Economics for a Warming World. New Haven: Yale University Press.

Office of Management and Budget. 2003. Circular A-4. http://www.whitehouse.gov/omb/circulars_a004_a-4.

Pindyck, Robert. 2013. "Climate Change Policy: What Do the Models Tell Us?" Journal of Economic Literature, 51(3): 860-72.

Sen, Amartya. 2009. The Idea of Justice. Cambridge, MA: Harvard University Press. 
Stern, Nicholas. 2013. "The Structure of Economic Modeling of the Potential Impacts of Climate Change: Grafting Gross Underestimation of Risk onto Already Narrow Science Models." Journal of Economic Literature 51 (3): 838-59.

Sunstein, Cass R. 2013. "The Office of Information and Regulatory Affairs: Myths and Realities." Harvard Law Review 126 (6): 1838-78.

Weitzman, Martin L. 1998. "Why the Far-Distant Future Should Be Discounted at Its Lowest Possible Rate." Journal of Environmental Economics and Management. 36 (3): 201-08. 